\title{
Pension System as a Limitation Factor on the Development of the Economy of the Republic of Srpska
}

\author{
Zoran Mastilo ${ }^{1}$ \\ Faculty of Business Economics, University of East Sarajevo, Bijeljina, Bosnia and Herzegovina \\ zoran.mastilo1964@gmail.com
}

Keywords: Pension system; national economy; PAYG system; financial markets; business growth; unemployment; demographic projections.

\begin{abstract}
The aim of this paper is to, by means of comparative analysis, demonstrate that the contemporary pension systems are actually limitation factors of development of the Republic of Srpska and that they should be both reformed and improved. Ultimately, pension systems should serve as the foundation for development of the Republic of Srpska. They should provide significant improvement to strengthening financial markets, enhancement of capital markets, higher employment rated and higher growth rates of the Republic of Srpska. Private pension funds should alter their principles, as well as ideas of every prospective insurance holder, aiming to make the pension rights a matter of concern of individual, instead of being the obligation and ballast to the society. Nowadays, stabile financing of pension systems and their respective funds is an increasingly questionable issue. There is an increasing gap between the area of rights gained by law and financial possibilities for their actual implementation. Pay-as-you-go (PAYG) systems, i.e. systems of intergeneration solidarity are particularly endangered. Adequate systematization of gathered data, i.e. evidence, should provide conclusions that pension systems are often a burden and limitation to development of national economy. This claim is present in underdeveloped and developing countries, whereas the developed economies are also facing grave problems.
\end{abstract}

\section{Introduction}

Social policy and social issues are a challenge for any society. Most countries face a constant increase in the need for social benefits and the ever-scarce funds for their financing. Pension systems feature wide-ranging and important effects, as they influence the living standards of pensioners and hence the welfare of both pensioners and their children. They can also affect national economic performance through potential effects on the labour supply and saving. The design of pensions therefore matters [1]. As a pillar of social security, the pension system is one of the most important and most sensitive economic issues in the Republic of Srpska. A pension system is a challenge for any society, particularly for transitional societies, whereby even developed economies are in fear of resolving the Social policy issues. Due to insufficient financial resources collected by means of contributions for pension and disability insurance, the Republic of Srpska continuously maintains the use of funds from its own budget to provide the outstanding funds for the payment of the acquired levels of pension rights. This paper aims to demonstrate by means of analysis, that the Pension System is a limitation on the development of the economy of the Republic of Srpska. Such a system needs to be reformed, transformed and improved, thus providing it with a safe and secure future. Ultimately, the pension system should be the basis for the development of the national economy. It can only be done by establishing self-sustaining pension systems. The experience of other countries that have had problems with their pension systems and sought solutions to regulate their pension systems should not be neglected. One of the examples that may be used by the Republic of Srpska is the pension reform executed in Chile [2]. ${ }^{1}$ Such reform model contributes to higher growth rates in national

\footnotetext{
${ }^{1}$ The arrangements in Chile were highly influential in Latin America and elsewhere. Beginning in the1990s Peru (1993), Argentina (1994), Colombia (1994), Uruguay (1996), Bolivia (1997), Mexico (1997), El Salvador (1998), Ecuador (2001), Costa Rica (2001), the Dominican Republic (2003-05), and Panama (2005-07) introduced structural reforms. These reforms had distinct aspects and characteristics, but they all shared a common objective: to make their social
} 
economies, higher employment levels and the strengthening of financial markets. Pension funds in developed countries (USA, Canada and Sweden) are one of the most important institutional investors in the financial markets. Systems based on intergenerational solidarity (Pay as you go systems) are facing unsustainability in all of the countries they exist in, which is why a reform is necessary to be executed in the direction that will enable those solutions to ensure a secure future for the pension system in the long run. For such solutions it is necessary to change the habits and behaviours of each future insured person with the aim of ensuring that the pension right becomes the matter of care and concern of every individual, not the care or burden of the society as a whole. The subject of the paper is socially justified and perhaps even necessary, to prove whether the pre-set hypothesis can indeed be confirmed by means of empirical research. Adequate systematization of the collected data or evidence should provide a conclusion if the Pension System restricts the development of the economy of the Republic of Srpska. This claim is present in underdeveloped countries and developing countries. However, developed economies are also facing severe challenges in that respect.

\subsection{Objectives of the Paper}

1. To ensure long-term future of the pension system of the Republic of Srpska and its sustainability.

2. To instigate development of the Republic of Srpska

3. To implement systemic reform of the pension system in the Republic of Srpska.

\subsection{Hypothesis}

Pension system represents a limitation to the development of the Republic of Srpska.

\section{Literature Review}

The literature review for this paper has been divided into three phases which include the conceptual framework, theoretical and empirical research.

\subsection{Conceptual framework}

\subsubsection{Emergence and development of pension-disability insurance fund}

The beginnings of the development of the pension insurance system date back to 1889 , when the German chancellor Otto Bismarck formed a pension system for industrial workers aged 70 and over, with the aim of providing them with income in old age. This system is known as the system of intergenerational solidarity or the so-called pay-as-you-go system, which still functions in most countries of the world. Shortly thereafter, in 1891, Denmark, and later New Zealand, established a pension system named „Beveridge system“, in order to reduce the poverty of the entire elderly population, whose pensions are financed from tax revenues i.e. from the budget. A smaller number of countries nowadays feature such system of financing pensions. The academic public is divided in terms of what category the pension belongs to, i.e. if it is an economic or a social category. It would be reasonable if the pension was primarily an economic category and only then a social category. By means of a more detailed analysis of pension insurance, it can be concluded that there are two types of pension system:

- system of current (annual) adjustment of contributions with social security payments (pay-asyou-go system) and

- system of capital accumulation (funded system).

The current financing system is the dominant system worldwide.

The pension system is considered adequate if it succeeds in fulfilling both objectives. This means providing material security in the old age for certain categories of workers and officials, whose employers have taken responsibility for their social protection. This is how a redistributive system of 
financing was created, more commonly known as a "pay as you go" system, i.e. a system of intergenerational solidarity. Pay-as-you-go (PAYG) pensions are paid out of the current revenue (usually by the state, from tax revenue) rather than out of accumulated funds. Partially funded pensions are often referred to as PAYG. [3]

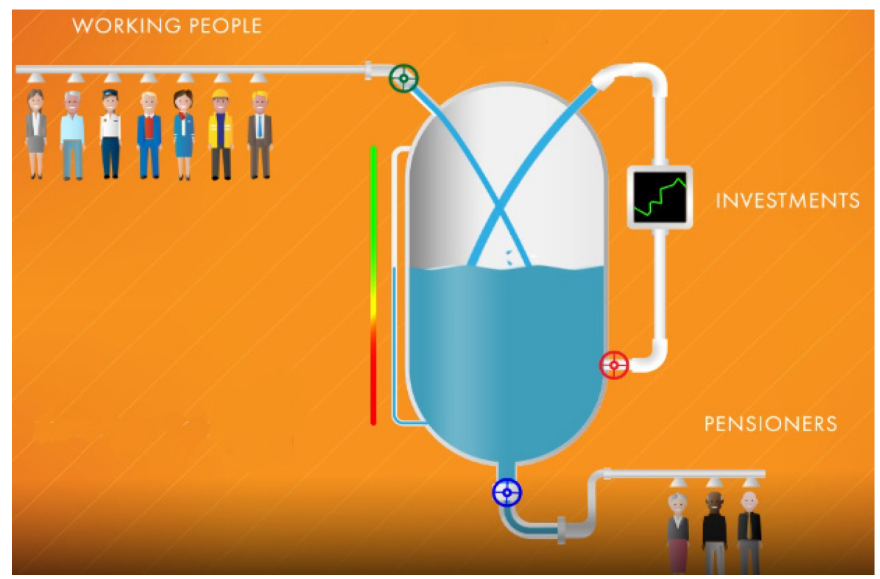

Figure 1. Graphic representation of,,pay as you go " pension model. Source: AVVAcademie [4].

The Fig. 1 represents the ideal (theoretical) functioning of the "pas as you go" pension system model according to which the ratio of contributors and pension beneficiaries must be at least $3: 1$. In this case, the pension system is self-sustaining and the surplus of any funds necessary for the payments of pension beneficiaries is invested in the financial markets. Nowadays, the functioning of the "pay as you go" system is far from ideal. This model is undergoing reforms in almost all the countries in which it is being implemented. The pension and disability insurance system of the Republic of Srpska is the legacy of the former pension and disability system of Bosnia and Herzegovina that was legally existing until 1 April 1992. The pension system of Bosnia and Herzegovina from that time, as well as in most of the socialist countries, operated on the principle of intergenerational solidarity (Pay as you go - PAYG system). The functioning of the pension system in the Republic of Srpska depends on many factors: political stability, GDP growth, unemployment / employment rates, amount of wages, fiscal policy and revenue collection, demographic trends and population structure, foreign trade with other countries, etc. Below, we analyse all of the above indicators in the Republic of Srpska and their impact on the pension system.

\subsection{Theoretical Review - Pension-disability insurance of the Republic of Srpska}

\subsubsection{Ratio of the number of insured people and pension beneficiaries}

Table 1. Insured people and pension beneficiaries ratio in the Republic of Srpska from 2012-2018.

\begin{tabular}{|c|c|c|c|}
\hline Year & Insured & Pension Beneficiaries & Ratio \\
\hline 2012 & 276.195 & 238.576 & 1,16 \\
\hline 2013 & 276.267 & 244.684 & 1,13 \\
\hline 2014 & 280.511 & 249.279 & 1,13 \\
\hline 2015 & 286.310 & 252.213 & 1,14 \\
\hline 2016 & 292.811 & 257.609 & 1,14 \\
\hline 2017 & 300.202 & 260.580 & 1,15 \\
\hline 2018 & 304.494 & 261.616 & 1,16 \\
\hline
\end{tabular}

Source: The Pension and Disability Insurance Fund of the Republic of Srpska [5]. 
Table 1 indicates the poor relationship between the number of beneficiaries and insured people, i.e. of contributors in the Republic of Srpska. This relationship maintains a worsening trend on a yearly basis, indicating that the current pension system is unsustainable in the long-term and has no future in its current form. Therefore, this should be considered as an alarm for the Republic of Srpska and its pension system. We have already noted that the "pay as you go" pension system could function flawlessly if the ratio between the number of insured (contributors) and pension beneficiaries would be at least 3:1. In other words, if each pensioner would be covered by 3 contributors, the system would function smoothly. In the Republic of Srpska this ratio is far from the required one. According to the latest data from the Bulletin of Pension and Disability Insurance Fund of the Republic of Srpska, Volume 08, August 2018 [6], one pensioner is covered only by 1.16 contributors. With respect to the above, the funds collected on the basis of payment of contributions to the Pension and Disability Insurance Fund are insufficient for the payment of pensions both in terms of monthly and annual payments.

By utilising the sampling method, revenues and expenditures for 2015 and 2016 were analysed based on the data from the Information on the situation in Pension and Disability Insurance in the Republic of Srpska [7].

Table 2. Structure of total revenues for year 2016.

\begin{tabular}{|c|c|c|c|c|}
\hline \multicolumn{1}{|c|}{ Revenues (BAM) } & Year 2015 & \% share & Year 2016 & \% share \\
\hline Contributions' based revenues & 755.941 .491 & 98,81 & 763.613 .829 & 98,65 \\
\hline Other revenues & 9.105 .733 & 1,19 & 10.445 .700 & 1,35 \\
\hline TOTAL & $\mathbf{7 6 5 . 0 4 7 . 2 2 4}$ & $\mathbf{1 0 0}$ & $\mathbf{7 7 4 . 0 5 9 . 5 2 8}$ & $\mathbf{1 0 0}$ \\
\hline
\end{tabular}

Source: Information on the situation in Pension and Disability Insurance in the Republic of Srpska [7].

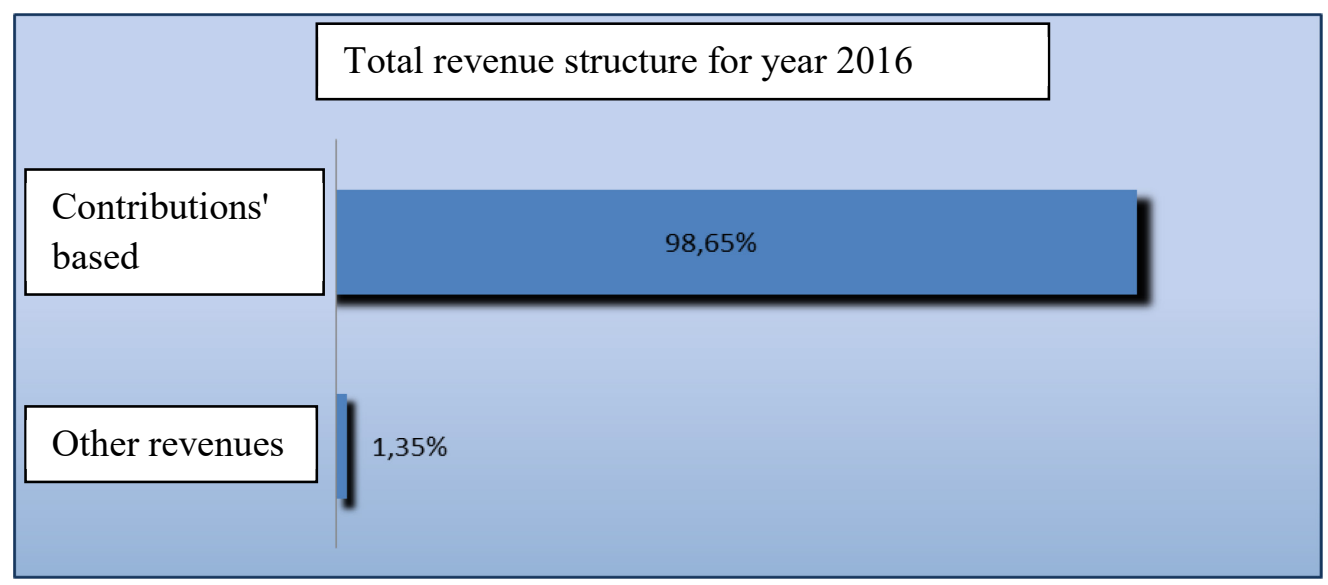

Figure 2. Structure of total revenues for 2016.

Source: Information on the situation in Pension and Disability Insurance in the Republic of Srpska [7]. 
Table 3. Structure of total revenues for year 2016.

\begin{tabular}{|l|c|c|c|c|}
\hline \multirow{2}{*}{\multicolumn{1}{|c|}{ Type of revenue }} & \multicolumn{2}{|c|}{ Year 2015 } & \multicolumn{2}{c|}{ Year 2016 } \\
\cline { 2 - 5 } & amount & $\begin{array}{c}\text { \% share in } \\
\text { total revenue }\end{array}$ & amount & $\begin{array}{c}\text { \% share in } \\
\text { total revenue }\end{array}$ \\
\hline $\begin{array}{l}\text { 1. Contributions } \\
\text { (1.1+1.2+1.3+1.4) }\end{array}$ & 755.941 .491 & 98,81 & 763.613 .829 & 98,65 \\
\hline 1.1. Standard contributions & 743.426 .246 & 97,17 & 738.954 .107 & 95,23 \\
\hline 1.2. Outplacement services & 1.905 .218 & 0,25 & 2.643 .533 & 0,34 \\
\hline 1.3. Contributions - bonds & 1.132 .308 & 0,15 & 364.189 & 0,05 \\
\hline 1.4. Share-based contributions & 0 & 0,00 & 2.440 .394 & 0,32 \\
\hline $\begin{array}{l}\text { 1.5. Contributions based on } \\
\text { Minutes from Taxation } \\
\text { Authority }\end{array}$ & 0 & 0,00 & 1.236 .497 & 0,16 \\
\hline 1.6. Multilateral compensation & 9.477 .719 & 1,24 & 17.975 .109 & 2,32 \\
\hline 2. Other revenues & 9.105 .733 & 1,19 & 10.445 .700 & 1,35 \\
\hline \multicolumn{1}{|c|}{ TOTAL (1+2) } & 765.047 .224 & 100,00 & 774.059 .528 & 100,00 \\
\hline
\end{tabular}

Source: Information on the situation in Pension and Disability Insurance in the Republic of Srpska [7].

Table 4 indicates the composition of total expenditures in years 2015 and 2016.

Table 4. Total expenditures for 2015 and 2016.

\begin{tabular}{|c|c|c|c|c|c|}
\hline Total expenditures & $\begin{array}{c}\text { Expenditures } \\
2015\end{array}$ & $\begin{array}{c}\text { Expenditure } \\
\text { percentage } \\
\mathbf{2 0 1 5} \\
\end{array}$ & $\begin{array}{l}\text { Expenditures } \\
2016\end{array}$ & $\begin{array}{c}\text { Expenditure } \\
\text { percentage } \\
2016 \\
\end{array}$ & $\begin{array}{c}\text { Index } \\
(4: 2)\end{array}$ \\
\hline 1 & 2 & 3 & 4 & 5 & 6 \\
\hline $\begin{array}{l}\text { Pensions, funeral costs, } \\
\text { damage claims and fees as } \\
\text { per the regulation of the } \\
\text { Government of the } \\
\text { Republic of Srpska }\end{array}$ & 970.378 .992 & 96,88 & 980.358 .670 & 96,99 & 101,03 \\
\hline Pensioners' Health care & 9.558 .709 & 0,95 & 9.610 .637 & 0,95 & 100,54 \\
\hline Pension distribution & 4.523 .840 & 0,45 & 3.206 .883 & 0,32 & 70,89 \\
\hline $\begin{array}{l}\text { Expenditures forthe } \\
\text { achieved level of pension } \\
\text { rights (pensions, } \\
\text { insurances, etc.) }\end{array}$ & 984.461 .541 & 98,29 & 993.176 .190 & 98,26 & 100,89 \\
\hline Employees' gross salaries & 13.286 .660 & 1,33 & 13.127 .561 & 1,30 & 98,80 \\
\hline $\begin{array}{l}\text { Employees' costs' } \\
\text { reimbursements }\end{array}$ & 422.905 & 0,04 & 371.947 & 0,04 & 87,95 \\
\hline Expert services costs & 3.439 .808 & 0,34 & 4.104 .009 & 0,41 & 119,31 \\
\hline $\begin{array}{l}\text { Administrative } \\
\text { expenditures }\end{array}$ & 17.149 .374 & 1,71 & 17.603 .517 & 1,74 & 102,65 \\
\hline $\begin{array}{l}\text { Expenditures in the given } \\
\text { period }\end{array}$ & 1.001 .610 .914 & 100,00 & 1.010 .779 .707 & 100,00 & 100,92 \\
\hline $\begin{array}{l}\text { Expenditures for non- } \\
\text { financial assets }\end{array}$ & 1.027 .981 & & 173.228 & & 16,85 \\
\hline Total expenditures & 1.002 .638 .896 & & 1.010 .952 .935 & & 100,83 \\
\hline
\end{tabular}

Source: Information on the situation in Pension and Disability Insurance in the Republic of Srpska [7]. 
Tables 2, 3 and 4, as well as Fig. 2 show that the contribution rate is completely inadequate for the Pension and Disability Insurance and that it does not provide for the necessary amount of funds on a monthly and annual basis.

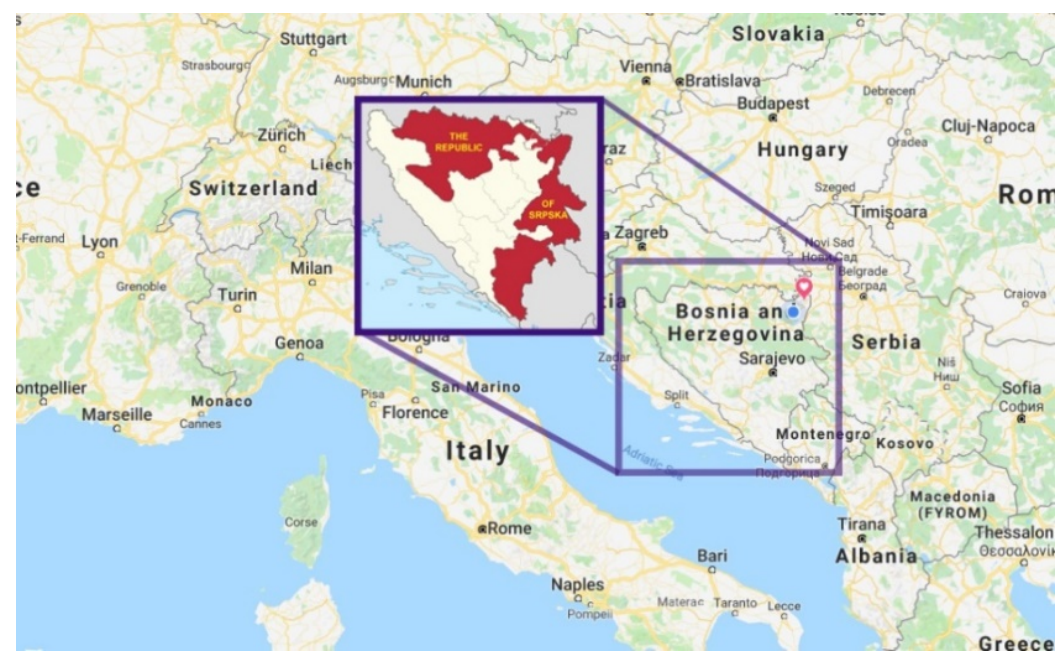

Figure 3. Map of Republic of Srpska.

Source: [8].

Therefore, the system of Pension and Disability Insurance Fund of the Republic of Srpska faces an enormous problem, with no solution offered on how to provide additional financial resources for meeting and maintaining the achieved level of pension rights. The competent fund has redirected this problem to the Government of the Republic of Srpska to be resolved, which is why the government borrows money from commercial banks with respective interest rates, in order to provide the outstanding funds for payment of the reached level of pension rights [9]. As the funds collected by payment of contributions to the Pension and Disability Insurance Fund are insufficient for the payment of compulsory pension insurance [9], the Government of the Republic of Srpska was forced to use funds from the budget for covering outstanding assets in the cash flows of the pension fund each month.

\begin{tabular}{|l|r|}
\hline Year & Funds outstanding \\
\hline $\mathbf{2 0 1 1}$ & 193.000 .000 BAM \\
\hline $\mathbf{2 0 1 2}$ & 156.000 .000 BAM \\
\hline $\mathbf{2 0 1 3}$ & 156.000 .000 BAM \\
\hline $\mathbf{2 0 1 4}$ & 185.000 .000 BAM \\
\hline $\mathbf{2 0 1 5}$ & $237.591 .672 \mathrm{BAM}$ \\
\hline $\mathbf{2 0 1 6}$ & $236.893 .407 \mathrm{BAM}$ \\
\hline $\mathbf{2 0 1 7}$ & 212.201 .228 BAM \\
\hline TOTAL & $\mathbf{1 3 7 6} \mathbf{7 4 4} \mathbf{5 7 2}$ BAM \\
\hline
\end{tabular}

Figure 4. Funds outstanding, BAM.

Source: Information on situation on Pension and Disability Insurance of the Republic of Srpska, Banja Luka, June 2017, p.13, 15-16 [9].

The Government of the Republic of Srpska disburses the outstanding funds from its own budget, which in fact represents a limitation on the development of its economy. If we were to compare this with the incentives' allocations that the Government executed through the Ministry of Industry, Energy and Mining (the competent ministry) amounting to 66,950,000 BAM (according to 
the data of RS budget [10] from 2011 to 2017, a disbalance or disproportion is more than evident. It is clear that the Government of the Republic of Srpska allocates significantly more funds for tending to social matters in comparison to the funds allocated for the stimulation of economic development.

Table 5. Total debt of the Republic of Srpska (in million BAM) and share of total debt in the Republic of Srpska's GDP from 2011 - 2017.

\begin{tabular}{|c|c|c|c|}
\hline Year & Total Debt & GDP Percentage & $\begin{array}{c}\text { Share of deficit of Pension and } \\
\text { Disability Fund in RS GDP }\end{array}$ \\
\hline 2011 & 4.249 & 48,80 & 2,22 \\
\hline 2012 & 4.669 & 54,20 & 1,81 \\
\hline 2013 & 4.705 & 53,50 & 1,77 \\
\hline 2014 & 5.055 & 56,90 & 2,08 \\
\hline 2015 & 5.277 & 57,30 & 2,06 \\
\hline 2016 & 5.440 & 56,50 & 2,55 \\
\hline 2017 & 5.315 & 53,20 & 2,10 \\
\hline
\end{tabular}

Source: Ministry of Finance of the Republic of Srpska [11].

The total debt of the Republic of Srpska from 2011 to 2017 is shown in Table 5, whereas according to the data of the Ministry of Finance, as of 31 March 2018, the total debt of the Republic of Srpska that is subject to legal limitation amounts to 5,341.42 mil. BAM (50.87\% of GDP), with the public debt subject to legal limitation amounting to 4,229.84 mil. BAM (40.28\% of GDP). Debt balance based on credit indebtedness which the Government of the Republic of Srpska issued guarantees for amounts to 312.48 mil. BAM (2.98\% of GDP), which is the total exposure of the Republic of Srpska under the issued guarantees. One of the reasons for the ongoing borrowing policy of the Government of the Republic of Srpska was certainly the lack of funds in the pension fund. It is only logical to conclude that such pension system is a limitation factor on the development of the economy of the Republic of Srpska, therefore requiring urgent reform. The projections in support of such statement have been already mentioned on p.3 of the paper, specifying the amount the Government allocated from the budget for the purpose of financing the disbursement of pensions (1 376744572,00 BAM in the period from year 2011 to 2017). The given funds should have been used for the development of the economy of the Republic of Srpska, particularly in respect of its future infrastructure projects, that would give birth to new employment opportunities, therefore directly influencing the inflow of funds into the Fund and therefore its revenue. The outstanding funds that the Government of the Republic of Srpska allocated to the Pension and Disability Fund for the maintenance of liquidity should have been directed to large infrastructure projects, in order to strengthen the investment cycle and to aid in development of the Republic of Srpska. 


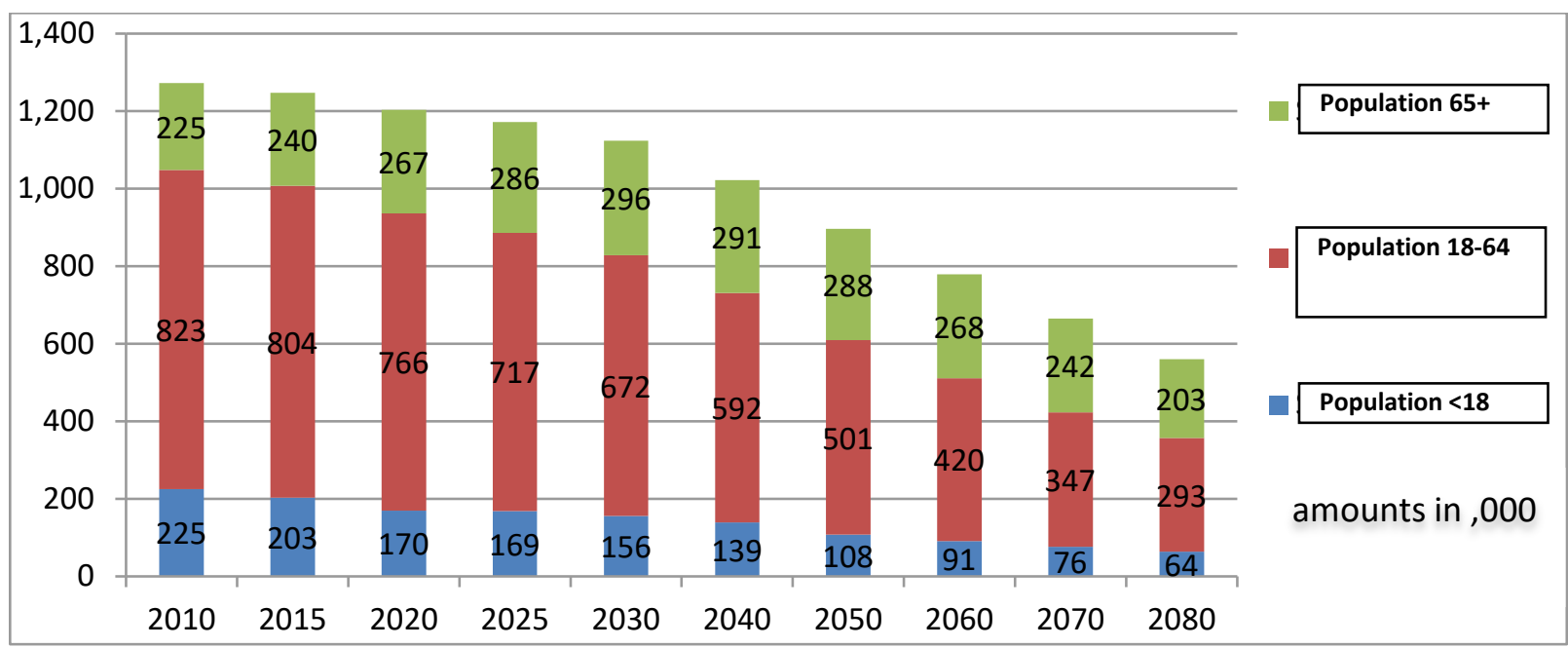

Chart 1. Demographic projection of population trends in the Republic of Srpska, at the fertility rate of 1.3 from $2010-2080$.

Source: Data collected from [12] and [13].

As evidenced from Chart 1 , the fertility rate in the Republic of Srpska is about 1.3. It was the basis for the projection of the population of the Republic of Srpska for the next 60 years. It is assumed that the fertility rate of $2.10-2.15$ should ensure the generational succession. This is a simple replacement of the generation, whereas the 1.3 rate indicates the disappearance of the population and the nation in the upcoming period, which is also indicated by a projection. This has a serious impact on the pension system, with the share of pensioners in the total population increasing from year to year. According to this projection, the participation of people over 65 (pensioners) in the total population structure in 2050 will amount to $47.20 \%$. The functioning of an economy with such population structure is very limited.

\subsection{Empirical review - Statistical model of the influence of inefficient pension system onto the economy of the republic of Srpska}

In order to point to the slowdown in the development of the economy of the Republic of Srpska, which faces increasing indebtedness, it was necessary to perceive all the relevant macroeconomic indicators that reflect the state of the economy and public sector of the Republic of Srpska. This primarily refers to the nominal amount of GDP, then to the amount of total and public debt, the amount of investments in fixed assets, as well as the amount of the outstanding funds of the Pension and Disability Fund of the Republic of Srpska.

Table 6. Overview of Key Indicators for Statistical Analysis.

\begin{tabular}{|l|c|c|c|c|c|c|c|}
\hline \multicolumn{1}{|c|}{ Year } & $\mathbf{2 0 1 1}$ & $\mathbf{2 0 1 2}$ & $\mathbf{2 0 1 3}$ & $\mathbf{2 0 1 4}$ & $\mathbf{2 0 1 5}$ & $\mathbf{2 0 1 6}$ & $\mathbf{2 0 1 7}$ \\
\hline $\begin{array}{l}\text { Nominal GDP of RS } \\
\text { (mil. BAM), current } \\
\text { prices }\end{array}$ & $8.703,00$ & $8.615,00$ & $8.793,00$ & $8.887,00$ & $9.205,00$ & $9.631,00$ & $10.075,00$ \\
\hline $\begin{array}{l}\text { Realized fixed assets } \\
\text { investments (mil.BAM) }\end{array}$ & $1.382,00$ & $1.643,00$ & $1.564,00$ & $2.009,00$ & $1.651,00$ & $1.669,00$ & $1.612,00$ \\
\hline Public debt (mil.BAM) & $3.569,00$ & $3.770,00$ & $3.793,00$ & $4.091,00$ & $4.295,00$ & $4.347,00$ & $4.209,00$ \\
\hline Total debt (mil.BAM) & $4.249,00$ & $4.669,00$ & $4.705,00$ & $5.055,00$ & $5.277,00$ & $5.440,00$ & $5.315,00$ \\
\hline $\begin{array}{l}\text { Outstanding funds } \\
\text { Pension and Disability } \\
\text { Insurance Fund of RS } \\
\text { (mil.BAM) }\end{array}$ & 193,00 & 156,00 & 156,00 & 185,00 & 190,00 & 246,32 & 212,20 \\
\hline
\end{tabular}

Source: Data collected from the Ministry of Finance of the Republic of Srpska and the Pension and

Disability Insurance Fund of RS [14]. 
The analysis shown in Table 6 covers the period from year 2011 to 2017, given that the data on the outstanding funds before 2011 is not available. It was made using the SPSS statistics software and Microsoft Excel. Table 6 represents the display of data for the aforementioned indicators. At the very beginning, a descriptive analysis of the above data was made, whereas the following Table 7 provides an overview of the basic descriptive indicators.

Table 7. Descriptive analysis of basic macroeconomic indicators.

\begin{tabular}{|l|r|r|r|r|r|}
\hline \multicolumn{1}{|c|}{ Statistic } & $\begin{array}{c}\text { Nominal GDP } \\
\text { of RS (in mil. } \\
\text { BAM), current } \\
\text { prices }\end{array}$ & $\begin{array}{c}\text { Realized } \\
\text { fixed assets } \\
\text { investments } \\
\text { (in } \\
\text { mil.BAM) }\end{array}$ & $\begin{array}{c}\text { Public } \\
\text { debt (in } \\
\text { mil.BAM) }\end{array}$ & $\begin{array}{c}\text { Total debt } \\
\text { (in } \\
\text { mil.BAM) }\end{array}$ & $\begin{array}{c}\text { Outstanding } \\
\text { funds Pension } \\
\text { and Disability } \\
\text { Insurance } \\
\text { Fund of RS } \\
\text { (in mil.BAM) }\end{array}$ \\
\hline No. of observations & 7 & 7 & 7 & 7 & 7 \\
\hline Minimum & 8615,000 & 1382,000 & 3569,000 & 4249,000 & 156,000 \\
\hline Maximum & 10075,000 & 2009,000 & 4347,000 & 5440,000 & 246,320 \\
\hline Median & 8887,000 & 1643,000 & 4091,000 & 5055,000 & 190,000 \\
\hline Mean & 9129,857 & 1647,143 & 4010,571 & 4958,571 & 191,217 \\
\hline Standard deviation (n-1) & 543,112 & 187,038 & 300,034 & 432,271 & 31,624 \\
\hline Variation coefficient & 0,055 & 0,105 & 0,069 & 0,081 & 0,153 \\
\hline
\end{tabular}

Source: Data collected from the Ministry of Finance of the Republic of Srpska and the Pension and Disability Insurance Fund of RS [14].

Based on the calculated values from Table 7, it can be concluded that the average GDP in the observed period amounted to 9129,857 million BAM, that the average investments in fixed assets amounted to $1,647,143$ million BAM, that the public debt was 4010,57 million BAM, that the total debt was 4958,57 million BAM, and that the outstanding funds of the Pension and Disability Fund amounted to an average of 191,217 million BAM. The variation coefficient shows that the values are fairly homogeneous because the data variability ranges from $5.5 \%$ to $15.3 \%$. All the indicators record the minimum values in their initial and the maximum values in their final years of observation. Their movement will be shown by the following graphic representations.

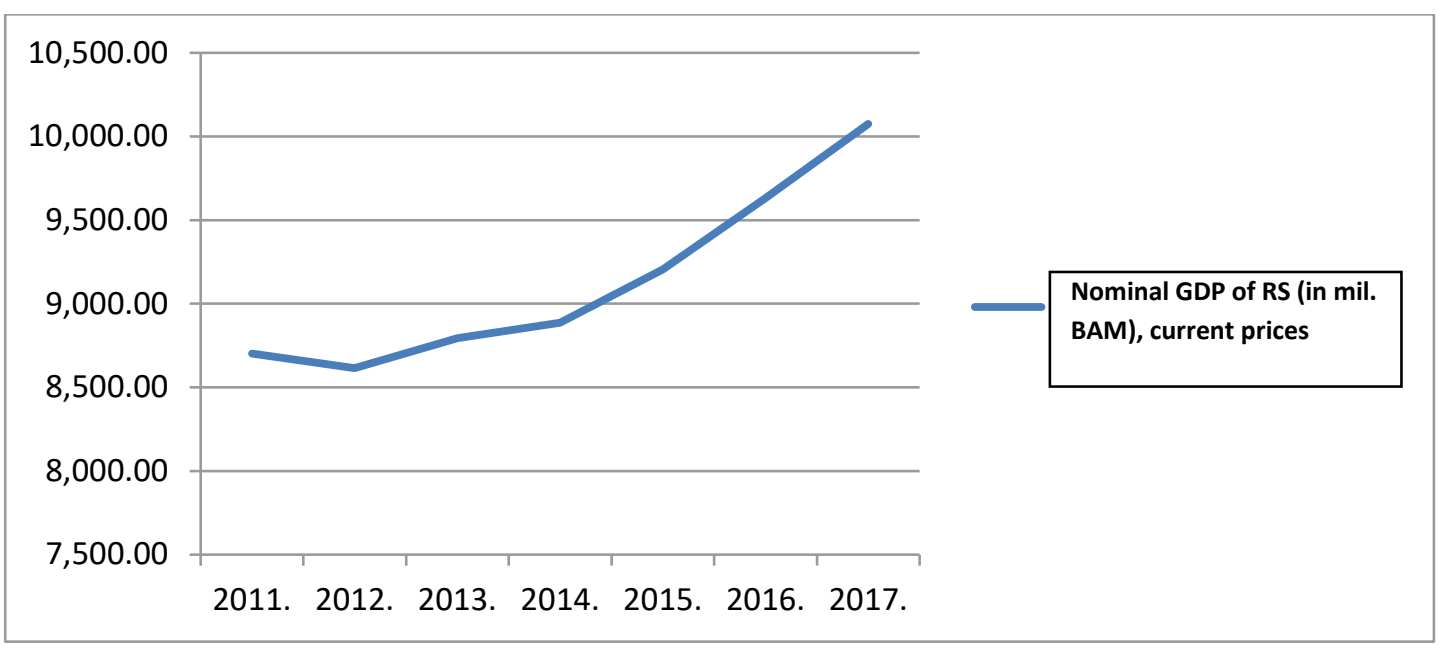

Chart 2. Nominal GDP of RS (in mil. BAM), current prices from 2011 to 2017.

Source: Ministry of Finance of the Republic of Srpska [15]. 
The graphic representation as shown in Chart 2 shows that the minimum value of GDP was registered in the year 2012, and that significant growth has been registered since 2014, thus reaching the amount of nearly 11 billion BAM in the year 2017.

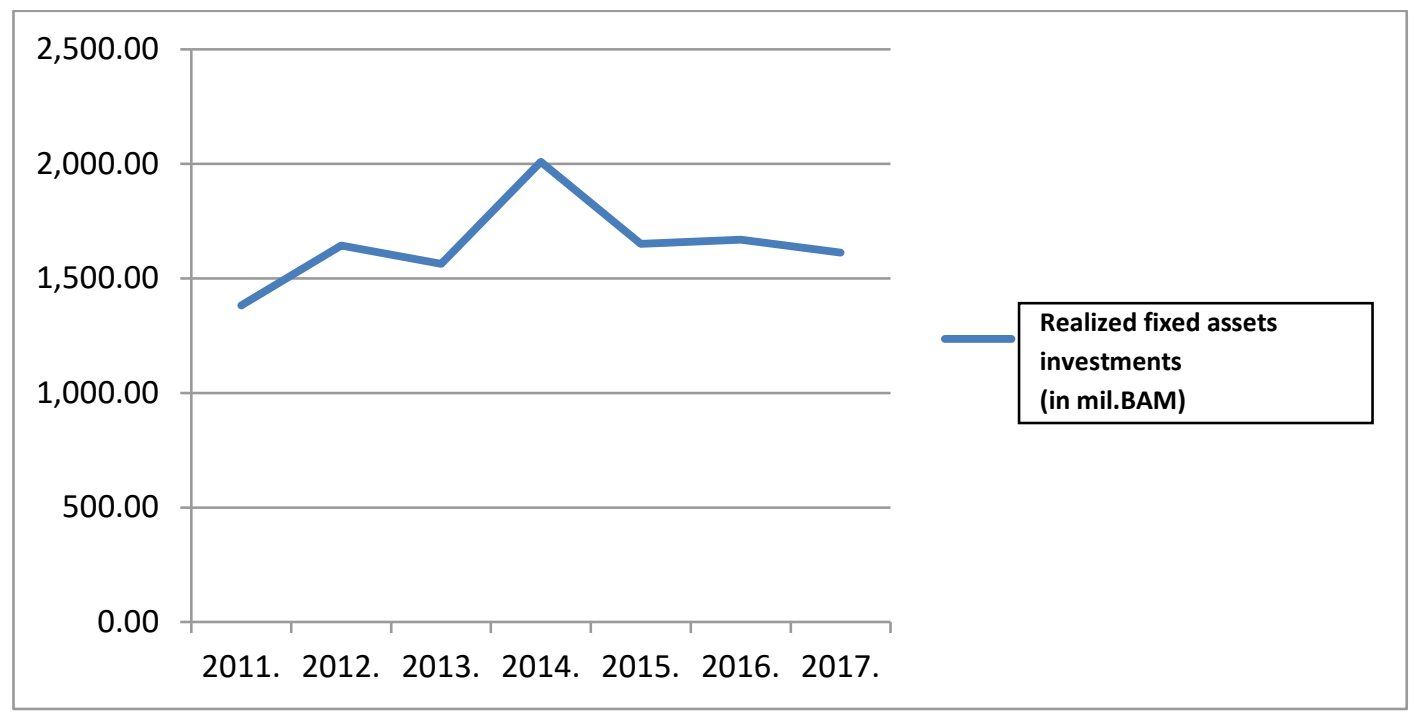

Chart 3. Realized fixed assets investments from 2011 to 2017 (in mil.BAM)

Source: Ministry of Finance of the Republic of Srpska [15].

Chart 3 illustrates the investments in fixed assets, on the basis of which it can be concluded that their minimum value was registered in the year 2011 , followed by a growth period. Its maximum was reached in the year 2014, whereby the investments have been declining over the past three years $(2015,2016,2017)$.

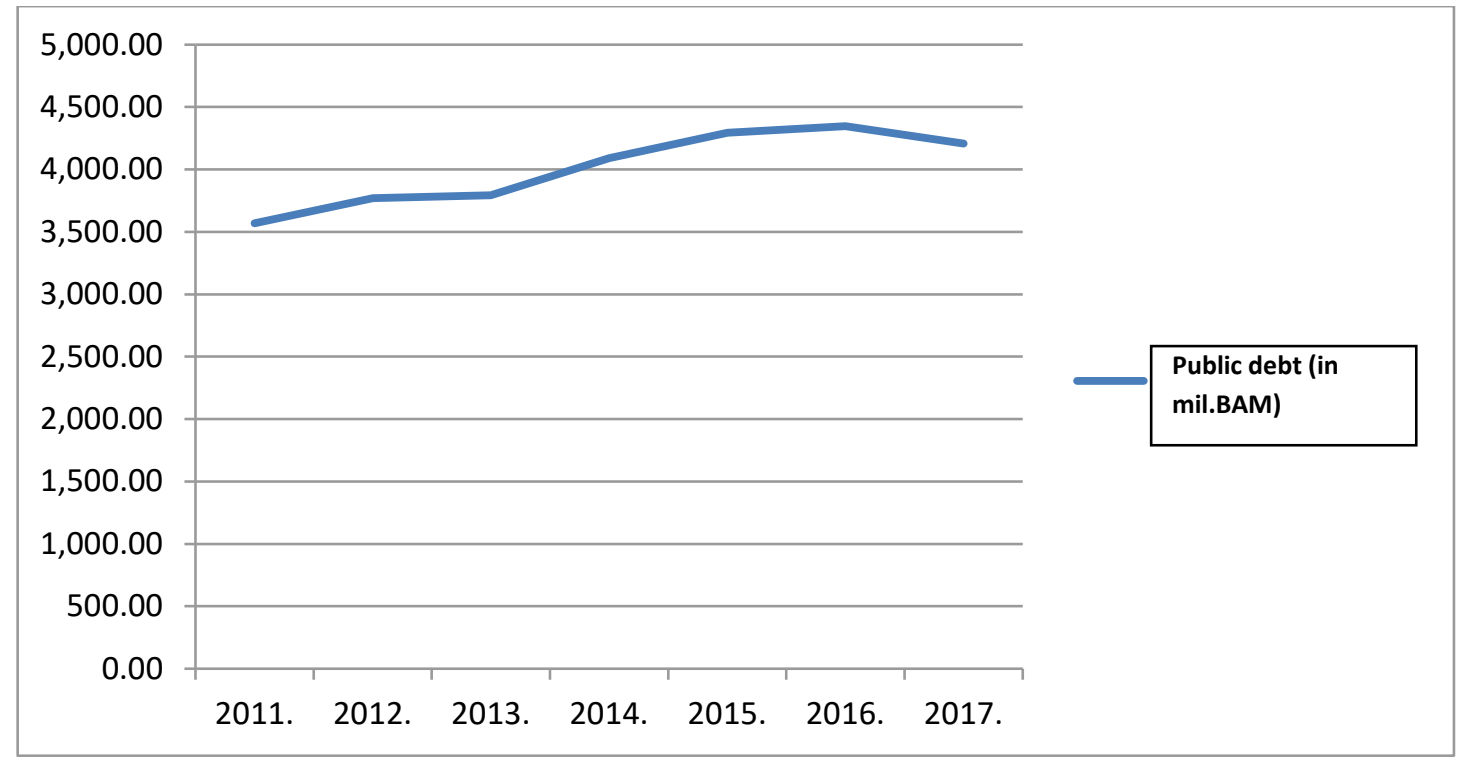

Chart 4. Public debt (in millions of BAM) of the Republic of Srpska from year 2011 to 2017. Source: Ministry of Finance of the Republic of Srpska [15].

As for the public debt shown in Chart 4, its constant growth can be noticed over the course of the observed period to the year 2016, with a slight decrease in public indebtedness in the last year there was. Debt of the Republic of Srpska ranges from 3,569 billion BAM to 4,347 billion BAM. 


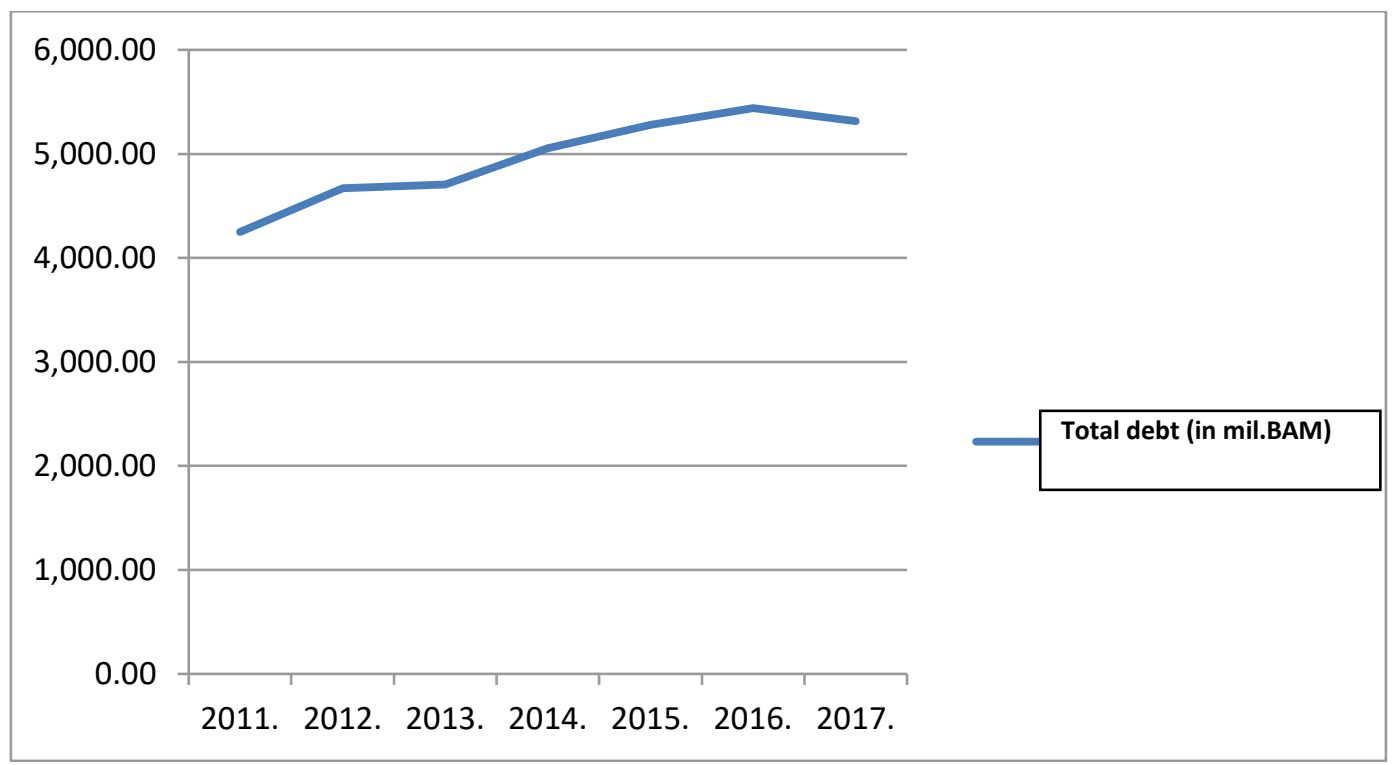

Chart 5. Total debt (in millions of BAM) of the Republic of Srpska from year 2011 to 2017. Source: Ministry of Finance of the Republic of Srpska. [15].

The results of the analysis demonstrated in Chart 5 are fairly identical to the one that precedes it, as the public debt comprises more than $80 \%$ of total debt.

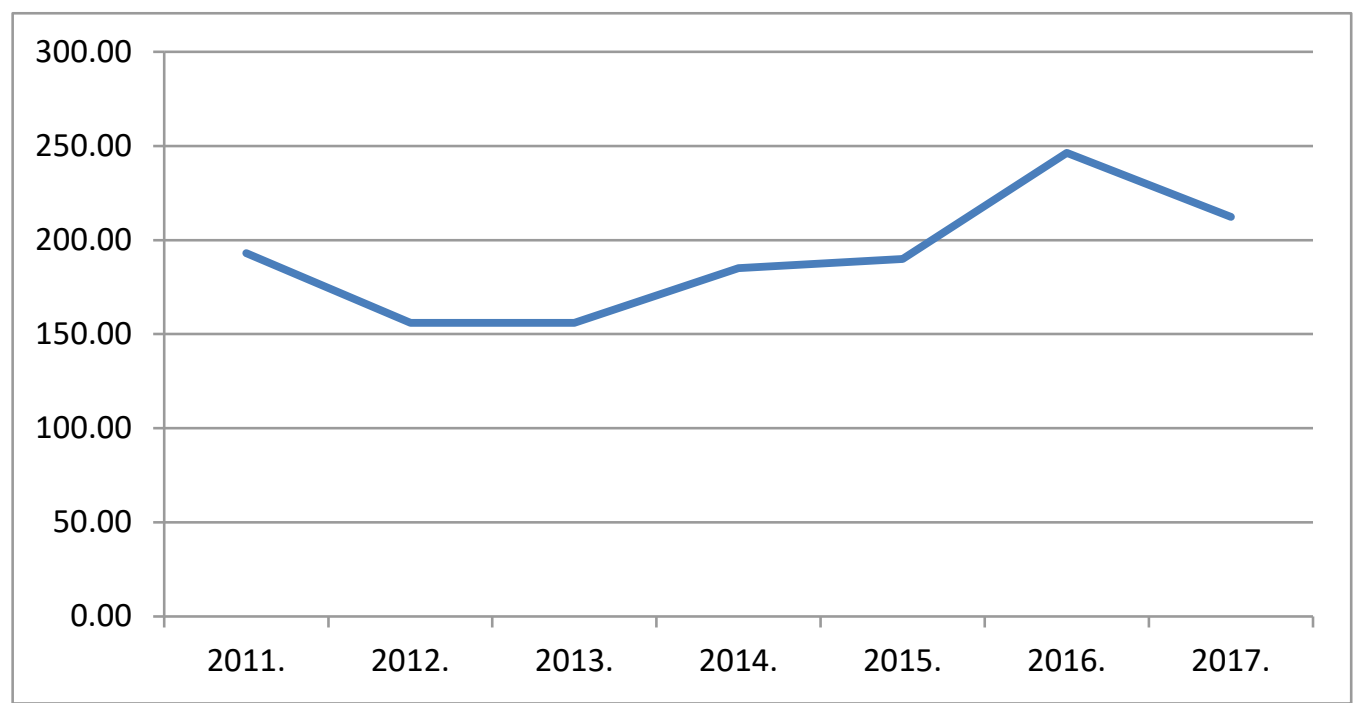

Chart 6. Outstanding funds Pension and Disability Insurance Fund (in millions of BAM) of RS from the year 2011 to 2017.

Source: Ministry of Finance of the Republic of Srpska [15].

Chart 6 focuses on the outstanding funds of the Pension and Disability Insurance Fund of the Republic of Srpska. It is evident that the situation was most alarming in year 2016, whereby the situation was the least worrying in 2012 and 2013. A slight drop has been registered in 2017, but judging by data from the first six months of 2018, it is estimated that the year 2018 will be even worse than 2016. In order to clearly demonstrate that GDP growth is not followed by the indebtedness growth, an additional analysis was also performed, which involved the calculation of the geometric growth rate for the observed indicators, which represents an average annual increase in a certain phenomenon. Table 8 shows data on chain index values and geometric growth rates. 
Table 8. Chain indices and geometric growth rates.

\begin{tabular}{|c|c|c|c|c|c|c|c|c|}
\hline Year & $\mathbf{2 0 1 1}$ & $\mathbf{2 0 1 2}$ & $\mathbf{2 0 1 3}$ & $\mathbf{2 0 1 4}$ & $\mathbf{2 0 1 5}$ & $\mathbf{2 0 1 6}$ & $\mathbf{2 0 1 7}$ & $\begin{array}{c}\text { Geometric } \\
\text { growth } \\
\text { rate (\%) }\end{array}$ \\
\hline $\begin{array}{c}\text { Nominal } \\
\text { GDP of RS } \\
\text { (mil. BAM) } \\
\text { current } \\
\text { prices }\end{array}$ & 104,4026 & 98,98885 & 102,0662 & 101,069 & 103,5783 & 104,6279 & 104,6101 & 2,74 \\
\hline $\begin{array}{c}\text { Realized } \\
\text { fixed assets } \\
\text { investments } \\
\text { (mil.BAM) }\end{array}$ & 94,20586 & 118,8857 & 95,19172 & 128,4527 & 82,18019 & 101,0902 & 96,58478 & 1,35 \\
\hline $\begin{array}{c}\text { Public debt } \\
\text { (mil.BAM) }\end{array}$ & 106,9203 & 105,6318 & 100,6101 & 107,8566 & 104,9866 & 101,2107 & 96,8254 & 3,37 \\
\hline $\begin{array}{c}\text { Total debt } \\
\text { (mil.BAM) }\end{array}$ & 110,421 & 109,8847 & 100,771 & 107,4389 & 104,3917 & 103,0889 & 97,70221 & 4,72 \\
\hline
\end{tabular}

Source: Data collected from the Ministry of Finance of the Republic of Srpska and the Pension and Disability Insurance Fund of RS [14]

The above table shows that the geometric growth rate for GDP amounts to $2.74 \%$, while being even less for realized investments, amounting to only $1.35 \%$. In contrast, the average growth in public debt over the observed period is $3.37 \%$, while the overall debt growth is $4.72 \%$. The data in question undoubtedly indicate that the rate of growth of indebtedness is nearly two times higher than the growth rate of GDP and more than three times higher than the rate of growth of investments, i.e. the funds collected by indebtedness are not used for the development of economic activity, but used to compensate for the outstanding funds of the Pension and Disability Insurance Fund of the Republic of Srpska.

\subsection{Research design and method of data analysis}

In order to further assess the link between the observed macroeconomic indicators, a correlation analysis was made, the results of which are shown in Table 9 below. Prior to making the analysis, it was necessary to prepare the respective data. Namely, all the observed data showed extremely nonstationary movement, which was verified by applying the augmented Dickey-Fuller test, which is a disruption of the assumptions for the application of correlation and regression analysis.

The equation for overcoming this problem includes differentiating logarithms of data from successive time series.

This method, instead of the specific levels of observed phenomena, observes their relative growth. The data observed include the period from year 2010 to 2017. It is important to note that Spearman's rank correlation coefficient, as not all data had a normal distribution.

Table 9. Statistical model - Correlation analysis

\begin{tabular}{|c|c|c|c|c|c|c|}
\hline & GDP & $\begin{array}{l}\text { Fixed assets } \\
\text { investments }\end{array}$ & $\begin{array}{c}\text { Public } \\
\text { debt }\end{array}$ & $\begin{array}{c}\text { Total } \\
\text { debt }\end{array}$ & $\begin{array}{c}\text { Fund } \\
\text { deficit }\end{array}$ & $\begin{array}{c}\text { Unemployment } \\
\text { rate }\end{array}$ \\
\hline GDP & 1,000 &,- 357 &,- 500 &,- 429 & ,393 &,- 357 \\
\hline $\begin{array}{ll}\text { Fixed } & \text { assets } \\
\text { investments } & \end{array}$ & & 1,000 & ,286 & 071 &, 036 &,- 143 \\
\hline Public debt & & & 1,000 & $893^{* *}$ & ,286 &, 036 \\
\hline Total debt & & & & 1,000 &, 036 & 286 \\
\hline Fund deficit & & & & & 1,000 &,- 286 \\
\hline Unemployment rate & & & & & & 1,000 \\
\hline
\end{tabular}

Source: Author 
As per data from Table 9, it is clear that only public debt and total debt are in a statistically significant correlation, which is direct and indicates that the growth of variable conditions the growth of the other, which is quite logical given the nature of these variables.

In addition to this correlation, other links are not statistically significant and lead us to the conclusion that GDP growth is not conditioned by major investments in fixed assets and the development of the corporate sector, nor is the decrease in employment a result of the economic investment.

Likewise, the lack of statistical significance in the relationship between the growth of public debt and fixed assets investments indicates that the funds obtained through debt are not spent for the purpose of developing the economy, but in the settlement of current liabilities, thereby also including the annual deficit of the Pension and Disability Insurance Fund.

The above analysis showed that debt growth is significantly higher than the GDP growth and the investments, whereby this analysis merely confirms these facts and indicates that borrowed funds are not spent on development, but are instead used for current consumption, which signals that GDP growth is not based on real economic bases, but on the consumption increase instead.

\section{Conclusion}

The economy of the Republic of Srpska belongs to the group of small economies in comparison to the economies of the countries in the region. Therefore, any unjustified spending of the budget funds represents a risk and a limitation for its development. We believe that the given financing of the outstanding funds to the pension system of the RS is unjustified and that it demonstrates that the functioning of the pension system in the Republic of Srpska is far from being ideal. This model of the pension system needs to undergo major reforms in order to become a self-sustaining one, which would save the enormous funds of taxpayers that are uncommittedly and unintendedly used from the budget of the Republic of Srpska. The pension system of the Republic of Srpska cannot independently finance the achieved level of pension rights, which is why the RS budget finances the outstanding funds in an unjustifiable manner, therefore significantly limiting the investment cycle. As shown in the correlation analysis, only the investment cycle of the Republic of Srpska directly affects the increase in gross domestic product, stability, the level of pension rights, the level of wages, the incentive for the development of local communities, private entrepreneurship, the development of infrastructure and the employment of young people. Negative demographic trends in the Republic of Srpska and beyond are one of the reasons for the urgently required reform of the current pension system of the Republic of Srpska, as that fact alone may prove itself as crucial in terms of establishing a sustainable pension system. The pension system of intergenerational solidarity, or so-called Bismarck model, was abandoned by the Government of the Republic of Srpska on 31 December 2015 when the entire system was brought into budget financing. It was an unreasonable and poorly planned decision of the RS Government, allowing the pension system to become a burden for the RS budget. This significantly slowed down the RS investment cycle and its development. Demographic trends in the Republic of Srpska are completely contrary to what the principle of pension system functioning requires. The society faces a greater number of deaths than new-borns, the continuous aging of the population, the departure of young people abroad (migration), low fertility rate and the other indicators mentioned above are worrying the society within the entity of RS. All of the above results in the fact that the today's pension system is becoming a constraint on the development of the economy of the Republic of Srpska. The developed statistical model proves that the geometric growth rate for GDP amounts to $2.74 \%$ and for the realized investments - only $1.35 \%$. In contrast, the average public debt growth over the observer period is $3.37 \%$, and the overall debt ratio amounts to $4.72 \%$. The data undoubtedly indicates that the indebtedness growth rate is nearly twice as high as the GDP growth rate, which is more than three times higher than the growth rate of investments. The statistics generated confirm that the funds collected by indebtedness are not used for the development of economic activity, but utilized for compensating the outstanding funds of the Pension and Disability Insurance Fund of the Republic of Srpska. Even before the transfer to the treasury-based operation of the Pension and Disability Fund of the Republic of Srpska, the government of RS has provided 
assistance by transferring budget funds on the basis of being obliged to do so, as per Article 154 of the Act on Pension and Disability Insurance of the Republic of Srpska, which refers to the so called "privileged rights", which monthly amounted to about 17000000 BAM. Once the transfer onto the treasury operations had been made, the Government of the Republic of Srpska has taken upon itself to finance any other outstanding funds to the Pension and Disability Insurance Fund from the budget, in addition to its previous financial obligations pursuant to Article 154 of the Act on Pension and Disability Insurance, for the purpose of pension payment, which amounted to about 28000000,00 BAM on a monthly basis. Thus, the only remaining solution for the pension system of the Republic of Srpska is a systemic reform, which should primarily and firstly analyse the transition cost, i.e. who will be the one covering it, knowing that significant funds are required for its coverage. The RS Government should now act in order to secure the future of the pension system in the long run.

\section{Acknowledgements}

Sincerest thanks to Mr. Dražen Bojagić, Student of Master Studies at the Faculty of Business Economics in Bijeljina, BIH, who prepared the data for Tables 1 and 5.

\section{References}

[1] Barr and Diamond's Reforming Pensions: Lessons from Economic Theory and Some Policy Directions, Economía, Brookings Institution Press, Volume 11, Number 1, Fall 2010, p.1

[2] N. Barr, P. Diamond (2016), 'Reforming pensions in Chile', Polityka Społeczna, No. 1, 2016, pp. 4-9. Available: http://econ.lse.ac.uk/staff/nb/Barr_and_Diamond_2016_Chile.pdf

[3] Barr and Diamond; Reforming Pensions: Lessons from Economic Theory and Some Policy Directions 2008,2010 p.2

[4] AVVAcademie. Available: https://bit.ly/2EuQy5g. Figure prepared by Mr. Dražen Bojagić, Student of Master Studies at the Faculty of Business Economics in Bijeljina, BIH,

[5] Pension and Disability Insurance Fund of the Republic of Srpska, http://www.fondpiors.org.

[6] Bulletin of Pension and Disability Insurance Fund of the Republic of Srpska, Volume 08, August 2018. Available: http://www.fondpiors.org/wp/wp-content/uploads/2018/02/08Statisticki-bilten-avgust-2018.doc

[7] Information on situation on Pension and Disability Insurance of the Republic of Srpska, Banja Luka, June 2017, p.13, 15-16. Available: http://e-vijecenarodars.net/wpcontent/uploads/2017/07/Informacija-o-stanju-u-oblasti-PIO-u-RS-za-2016.-godinu.pdf

[8] Google Maps. Available: https://www.google.com/maps.

[9] Information on situation on Pension and Disability Insurance of the Republic of Srpska, Banja Luka, June 2017. Available: http://e-vijecenarodars.net/wpcontent/uploads/2017/07/Informacija-o-stanju-u-oblasti-PIO-u-RS-za-2016.-godinu.pdf

[10] Ministry of Energy and Mining of the Republic of Srpska, available at: http://www.vladars.net/sr-SP-Cyrl/Vlada/Ministarstva/mper/Pages/default.aspx

[11] Data prepared by Mr. Dražen Bojagić, Student of Master Studies at the Faculty of Business Economics in Bijeljina, BIH, with reference to the Ministry of Finance of the Republic of Srpska. Available:

http://www.vladars.net/sr-SP-

Cyrl/Vlada/Ministarstva/mf/Pages/default.aspx

[12] Z. Mastilo, Pension and Health Insurance - Directions of Reform, second abridged edition (orig. Penzijsko i zdravstveno osiguranje - pravci reforme, drugo izmijenjeno i dopunjeno izdanje), Faculty of Business Economics in Bijeljina, 2013. 
[13] Reform strategy of the Pension System in the Republic of Srpska (orig. Стратегија реформе пензијског система у Републици Српској) Government of the Republic of Srpska, March 2010. Available: http://www.vladars.net/sr-SP-Cyrl/Vlada/Documents/Prijedlog\%20strategije $\% 20$ reforme $\% 20 \mathrm{PIO}-\% 20$ cirilica.pdf

[14] Table created and data prepared with reference to the Ministry of Finance of the Republic of Srpska and the Pension and Disability Insurance Fund of RS by Mr. Dražen Bojagić, Student of Master Studies at the Faculty of Business Economics in Bijeljina, BIH

[15] Ministry of Finance of the Republic of Srpska. Available: http://www.vladars.net/sr-SPCyrl/Vlada/Ministarstva/mf/Pages/default.aspx.

[16] R. Rofman, Argentina's pension policy in the last 20 years: Chronicle of a Death Foretold. Forbes.com, 2015. 